Revista lus et Praxis, Año 24, No 1, 2018, pp. 693 - 724

ISSN 0717 - 2877

Universidad de Talca - Facultad de Ciencias Jurídicas y Sociales

La hijuela pagadora de deudas y la responsabilidad por las deudas hereditarias

León Carmona Fontaine

Trabajo recibido el 14 de mayo de 2016 y aprobado el 19 de diciembre de 2016

\title{
La hijuela pagadora de deudas y la responsabilidad por las deudas hereditarias
}

\author{
THE PORTION OF THE ESTATE ASSIGNED TO COVER HERITABLE OBLIGATIONS
}

AND THE LIABILITIES ASSOCIATED WITH THE DEBTS OF THE ESTATE

León Carmona Fontaine*

\begin{abstract}
RESUMEN
En el presente trabajo, se estudia la obligación de formar la hijuela pagadora de deudas y su importancia en el régimen de responsabilidad por las deudas hereditarias. Se sostiene que la obligación de formar la hijuela pagadora de deudas otorga una protección especial a los acreedores de la herencia, en cuanto pretende asegurar el pago de sus créditos con el haber hereditario. Se explica la manera en que los acreedores pueden pedir su formación y la responsabilidad que conlleva el no formarla.
\end{abstract}

\section{ABSTRACT}

This article studies the obligation that executors have of forming a portion of assets, which is allocated to pay heritable obligations, also analyzing its significance for understanding the liabilities associated with the debts of the estate. The obligation of forming this portion of assets gives a security for heritable creditors, as secures its credits with the assets of the estate. The article also depicts how creditors can request this security and the liabilities involved therein.

\section{Palabras CLAVE}

Herencia, deudas hereditarias, partición de la herencia.

KEY WORDS

Estate, heritable obligations, distribution of the estate.

\section{Introducción}

Los artículos 1286, 1287, y 1336 del Código Civil' ${ }^{1}$, prescriben que en la partición de la herencia se forme un lote o hijuela de bienes suficientes para

\footnotetext{
* Abogado, Licenciado en Derecho de la Pontificia Universidad Católica de Chile. Profesor de Derecho Natural Pontificia Universidad Católica de Chile. Dirección Postal, Carmen Sylva 2851, Departamento 54, Providencia, Santiago. Dirección electrónica: plcarmon@uc.cl. El autor expresa sus agradecimientos a don José Joaquín Ugarte Godoy, por su ayuda y guía durante la preparación de este artículo. Asimismo, quisiera agradecer a Cristián Boetsch Gillet, quien habiendo leído un borrador de este artículo, realizó valiosas sugerencias y correcciones.

${ }^{1}$ Las menciones que en este texto se hacen al Código Civil se refieren al Código Civil chileno. Este mismo criterio se aplica para otros cuerpos normativos, salvo que exista referencia expresa a otras
} 
cubrir las deudas conocidas. Esta obligación recae tanto sobre el partidor como sobre el albacea y los herederos. En caso de no formarse esta hijuela pagadora de deudas, el albacea, los herederos y el partidor son responsables de todos los perjuicios que dicha omisión irrogue a los acreedores hereditarios.

El estudio consagrado por los autores nacionales a la hijuela pagadora de deudas no ha sido demasiado profuso. En general, su estudio se ha limitado a hacer referencia a las normas que establecen la obligación de formar la hijuela, sin profundizar en la implicancia que tiene esta institución en el régimen de responsabilidad por las deudas hereditarias ${ }^{2}$. Por su parte, la jurisprudencia tampoco ha ahondado en este asunto, encontrándonos con algún fallo recien$t^{3}$, en nuestra opinión de escaso acierto, que revela cuán desconocida ha terminado por ser la hijuela pagadora de deudas.

El presente trabajo tiene por objeto estudiar la hijuela pagadora de deudas, buscando entender la implicancia que tiene en el régimen de responsabilidad por el pago de las deudas hereditarias.

Sostenemos que esta institución otorga una protección especial a los acreedores de la herencia, en cuanto pretende asegurar el pago de sus créditos con el haber hereditario. En efecto, la hijuela pagadora de deudas consagra, en el derecho civil chileno, la obligación de los herederos de destinar los bienes de la herencia primeramente al pago de las deudas hereditarias conocidas.

Esta obligación afecta la manera general de entender el derecho sucesorio chileno, pues exige una cierta liquidación de la herencia que denota una relativa pervivencia del patrimonio del causante. Lo anterior, conlleva consecuencias prácticas importantes, tanto en lo que respecta al trato que deben dar los herederos a los bienes de la herencia y a las deudas hereditarias, como asimismo a la participación que cabe a los acreedores hereditarios en el proceso de liquidación y partición de la herencia.

En las secciones siguientes, ahondamos en esta cuestión. Para ello se revisan primero los antecedentes históricos de la hijuela pagadora de deudas (2). Posteriormente, se estudia la obligación de formar la hijuela pagadora de deudas en el Código Civil (3), tras lo cual se revisan algunas instituciones afines (4). Luego, se analiza la participación que cabe a los acreedores hereditarios en la formación de la hijuela pagadora de deudas (5). Se hace una revisión sobre la

jurisdicciones, o bien que, por el contexto o notoriedad, sea inequívoca la referencia a alguna jurisdicción distinta.

2 Ver entre otros Somarriva (2002), p. 393; Somarriva (2013), pp. 536-537; Domínguez Benavente y Domínguez Águila (1990), p. 580; RodríGuez (2002), p. 250; Elorriaga (2015), p. 671; LiRa Urqueta (1948), p. 129. En nuestra opinión, en donde mejor se trata la materia es en Claro Solar (2013), pp. 129-132. También resulta de utilidad consultar Claro SOLAR (2013), pp. 137-139.

3 Corte de Apelaciones de Chillán, 20 de julio de 2012. 
importancia de esta institución (6). Finalmente, se cierra con una sección de conclusiones.

\section{Antecedentes históricos de la hijuela pagadora de deudas}

\subsection{Roma}

Si bien en Roma no encontramos antecedentes directos de la hijuela pagadora de deudas ${ }^{4}$, en ciertas circunstancias los acreedores hereditarios tenían el derecho de exigir que los bienes de la herencia se destinasen preferentemente para el pago de sus deudas.

Así, y tal como explica Guzmán ${ }^{5}$, el beneficio de separación permitía mantener separados el patrimonio del heredero y los bienes de la herencia, de modo tal que los acreedores hereditarios ejecutasen sus créditos en los bienes sucesorios con preferencia a los acreedores del heredero. Este beneficio debía ser solicitado por alguno de los acreedores hereditarios en un proceso concursal ejecutivo ya iniciado. Concedida la separación de bienes, favorecía tanto al acreedor que la solicitó como a todos los restantes acreedores hereditarios que no hubiesen reconocido al heredero como deudor.

Un propósito similar cumplió la cautio suspecti heredis, la cual era concedida a los acreedores hereditarios para que el heredero sospechoso de insolvencia prestara una garantía para cubrir los créditos que poseyeran en contra de este. De no constituirla, el pretor permitía a los acreedores la misio in bona sobre la herencia, permitiendo la venditio bonorum, esto es, que tomaran posesión y procediesen a la venta de los bienes de la herencia ${ }^{6}$. Sin embargo, en caso que se probase que el heredero no había enajenado ningún bien de la herencia y no pudiese acriminársele nada excepto pobreza, se sustituía la carga de caucionar la deuda por la prohibición de enajenar los bienes de la herencia, sin que se procediese a la venta de los mismos.

Estas instituciones no pueden considerarse como antecedentes directos de la hijuela pagadora de deudas, pero manifiestan que ya desde Roma, los acreedores hereditarios tenían, bajo determinadas circunstancias, una cierta preferencia

\footnotetext{
4 Claro Solar menciona, como antecedente histórico de la hijuela pagadora de deudas, la cuarta denominada falcidia. Claro Solar (2013), p. 132. En realidad, si bien para efectos de calcular la cuarta falcidia era necesario determinar el valor liquido de la herencia, deduciendo para dicho fin las deudas, y así determinar la cuantía o importe de la cuarta de la herencia reclamada en queja sobre testamento contrario a deber o querela inofficiosi testamenti, no parece claro que la cuarta falcidia exigiese el pago efectivo de dichas deudas con los bienes de la herencia, sino que parce haber sido una operación contable. Véase GuZmán (2013), pp. 540 y ss.
}

5 GUZMÁ́n (2013), p. 620; KASER (1968), p. 336.

6 GUZMÁ́N (2013), p. 622; KASER (1968), p. 336. 
para ser pagados con los bienes de la herencia. En cierto modo, ello responde a una concepción jurídica natural, en virtud de la cual, los bienes de la herencia han de ser la base de la seguridad primordial y natural de los créditos de los acreedores hereditarios.

\subsection{Derecho Español Antiguo}

La hijuela pagadora de deudas propiamente tal parece haber surgido en el derecho hispano antiguo. Según las fuentes que conocemos, nace como consecuencia de los aforismos "antes es pagar que heredar" y "no hay herencia sino en el residuo", los cuales sintetizan el deber de destinar los bienes de la herencia preferentemente al pago de las deudas hereditarias.

En este sentido, en las Partidas existía la idea según la cual los bienes del causante debían destinarse primeramente al pago de las deudas hereditarias. Así, la herencia es definida como "la eredad, e los bienes e los derechos de algun finado; sacando ende las debdas que deuia e las cosas que y fallaren agenas $^{\prime \prime}$. Es decir, la herencia resultaba de deducir del patrimonio del causante las deudas y las cosas ajenas. Asimismo, las Partidas exigían el pago y no solo la deducción de las deudas del difunto antes de separar la cuarta Falcidia ${ }^{8}$. Las Partidas también prescribieron de manera expresa que determinadas deudas hereditarias debían pagarse antes de repartir los bienes entre los herederos ${ }^{9}$. Todavía más, en caso que el heredero pagase los legados antes que las deudas hereditarias y no lo que quedase más que el cuarto de la herencia, los acreedores hereditarios "deben demandar primeramente á los que obtuvieron las mandas, y están obligados á volverlas, y solo en caso de que no fueran bastantes á pagar las deudas deberá el heredero hacerlo de la cuarta parte que retuvo para $s i^{\prime \prime 10}$.

A este respecto, Peña Bernaldo de Quiroz sostiene lo siguiente: "[Las partidas dan un concepto residual de herencia] porque es la herencia -y no el patrimonio personal del heredero- la que está afecta a las deudas del causante y, por tanto, en principio, los acreedores del causante han de recibir las debdas en los bienes del finado (Cf. P. 6,6,7), los cuales constituyen la base de seguridad primordial y natural de sus créditos; porque por la sucesión el heredero no recibe, en definitiva, sino el residuo, o remanente, y mientras penden las cargas, la herencia no se confunde en el patrimonio del heredero"11.

\footnotetext{
7 Partida VII, 33, 8.

8 Partida VI, 6, 7; VI, 11, 2.

9 Partida I, 13, 12.

10 Partida VI, 6, 7.

11 Peña Bernaldo de Quiroz (2009), p. 25.
} 
Es probable que esta concepción propiamente castiza provenga del influjo que ejercieron los derechos godos en el naciente derecho castellano. En la mayor parte de dichos derechos, el heredero respondía de las deudas de la herencia solo con los bienes que había recibido y en un principio solo con los bienes muebles. Ello se reflejó en el Fuero Juzgo, en donde se establece que la responsabilidad de las deudas hereditarias debía satisfacerse solo con los bienes de la herencia ${ }^{12}{ }^{13}$.

Las Leyes de Toro, por su parte, refuerzan esta misma idea, dando a entender que las deudas hereditarias habían de pagarse antes de efectuar la partición. En particular, la Ley de Toro $\mathrm{N}^{\circ} \mathrm{XXI}$, permite al hijo o cualquier otro descendiente legítimo mejorado, repudiar la herencia y aceptar la mejora, con tal que sean primero pagadas las deudas del difunto que aparecieren al momento de la partición, pagándolas el mejorado a prorrata del valor de dicha mejora, y que por las deudas que aparecieren después, sea obligado a pagarlas en la misma proporción, como si el mejorado fuese heredero en la proporción de la mejora ${ }^{14}$.

Como sostiene Llamas y Molina, la Ley de Toro $\mathrm{N}^{\circ} \mathrm{XXI}$ supone que al momento de llevar a efecto la partición, previamente se habían satisfecho las deudas del difunto y que de los restantes, esto es de los que habían resultado luego de pagar las deudas, se había formado la división de la legítima y del quinto ${ }^{15}$.

Escriche confirma la tradición de la noción residual de herencia y la obligación de pagar las deudas de la herencia con los bienes de la herencia. El concepto herencia lo define como "el conjunto de los bienes y derechos que deja el difunto, deducidas las deudas ${ }^{\prime 16}$ y prescribe que las deudas hereditarias se paguen durante el proceso particional "pues solamente lo que resulta líquido y efectivo se llama herencia, y como tal es objeto de la partición"17.

\footnotetext{
12 Fuero Juzgo 5 y 6.

13 Mingorance Gonzálves (2004), p. 76. cierta parte de sus bienes."

15 Llamas y Molina (1852), p. 316.

16 ESCRICHE (1842), p. 284.

17 ESCRICHE (1842), p. 502.
}

14 En particular la Ley de Toro № 21 prescribe lo siguiente: "Mandamos que el hijo ó otro cualquier descendiente legítimo mejorado en tercio ó quinto de las bienes de su padre ó madre ó abuelos que puedan si quisieren repudiar la herencia de su padre é madre ó abuelos, é aceptar la dicha mejoría. Con tanto que sean primero pagadas las deudas del defuncto é sacadas por rata de la dicha mejoría las que al tiempo de la partija parecieren, e por los otras que después parecieren, sean obligados los tales mejorados a las pagar por rata de la dicha mejoría, como si fuesen herederos en dicha mejoría de tercio e quinto. Lo cual mandamos que se entienda, ora la dicha mejoría sea en cosa cierta, ó en 
De este modo, en la tradición jurídica española las deudas hereditarias debían pagarse antes de repartir los bienes entre los herederos y preferentemente con los bienes de la herencia.

Como consecuencia de dicha tradición, se entendió que en el evento que existiesen deudas no pagadas al momento de efectuar la partición, debían reservarse bienes para dicho propósito formando al efecto un lote o hijuela especial de bienes. En efecto, Tapia ${ }^{18}$ señala en su Febrero Novísimo, que en caso que existan deudas hereditarias que no hubiesen sido pagadas antes de la división de la masa hereditaria, el contador partidor debe constituir pagador de ellas a alguno de los interesados, adjudicándole la hijuela de deudas, y aplicando bienes o dinero para su solución hasta el importe de las mismas. Precisa Tapia, que por pagador de deudas se debía nombrar "al más abonado, fiel y exacto, con obligación de acreditar a los coherederos la satisfacción de ellas para su resguardo"19.

Tapia funda la adjudicación de estos bienes para pagar la hijuela adjudicada en que es primero pagar que heredar; y que no hay herencia hasta que están satisfechas las deudas. De este modo, la formación de esta hijuela de bienes es entendida como una consecuencia del carácter residual de la herencia y de la obligación de pagar las deudas de la herencia con los bienes de la herencia antes de llevar a efecto la partición.

La hijuela pagadora de deudas parece haber sido usual, pues se menciona en uno de los ejemplares de particiones que Tapia incluye en la parte final de su obra ${ }^{20}$.

En el derecho español moderno no existe la obligación de formar la hijuela pagadora de deudas sin que aparezca en el Proyecto de 1851 ni en el Código Civil español. Ello puede deberse quizás al influjo del Código Civil francés, el cual, como hace notar Peña ${ }^{21}$, influyó en que el Proyecto de 1851 tenga una concepción personalista de la sucesión hereditaria. También puede deberse a la "grande innovación contrario al Derecho Romano" 22 que adoptó el Proyecto de 1851, conforme a la cual hecha la partición, los herederos responden de manera solidaria de las deudas hereditarias ${ }^{23}$, terminando así con la regla según la cual las deudas hereditarias se dividen entre los herederos a prorrata de sus créditos.

\footnotetext{
TAPIA (1837), p. 84.

TAPIA (1837), p. 85.

TAPIA (1837), p. 404.

PeÑa (2009), p. 75.

García Goyena (1852), p. 281.

García (1852), p. 280.
} 
Sin embargo, y no obstante la influencia francesa, aún existe en alguna medida la persistencia del patrimonio hereditario en cuanto garante de las deudas hereditarias ${ }^{24}$. En particular, se les reconoce a los acreedores hereditarios el derecho de oponerse a que se lleve a efecto la partición, hasta que se les pague o afiance sus créditos. Asimismo, aun cuando sea de forma voluntaria, es común que en la partición se formen lotes de bienes destinados a pagar deudas hereditarias, adjudicados a uno o más herraderos para dicho fin ${ }^{25-26}$.

Las consideraciones contenidas en esta sección deben tenerse especialmente en cuenta. La influencia del derecho hispano en el proceso de codificación del derecho civil chileno, ha quedado de manifiesto en los estudios que al respecto se han efectuado. Como hace notar Guzmán, "desde el primer instante en que Bello tomó interés por la fijación del derecho civil, dejó en claro que ella debía basarse en el antiguo derecho romano-castellano heredado de la monarquía"27. Dicha influencia no solo fue ejercida por los cuerpos normativos del antiguo derecho hispano (i.e. las Partidas y las Leyes de Toro), sino que también por la antigua literatura jurídica del derecho hispano, entre la cual cabe mencionar las obras de Llamas, Escriche y Tapia ${ }^{28}$, a las que aquí hemos hecho referencia.

\section{La obligación de formar la hijuela pagadora de deudas en el Código Civil}

Los artículos 1286, 1287, y 1336 del Código Civil, prescriben que en la partición de la herencia se forme un lote o hijuela de bienes suficientes para cubrir las deudas conocidas. En caso de no formarse la hijuela pagadora de deudas, el albacea, los herederos y el partidor son responsables de todos los perjuicios que dicha omisión irrogue a los acreedores hereditarios.

\footnotetext{
24 PeÑa (2009), p. 76.

25 Mingorance (2004), pp. 113 y ss.

26 Para Lacruz, esta organización del pago de las deudas hereditarias no está pensada en beneficio de los acreedores, sino para liberar de la preocupación de ese pago a la colectividad de los herederos, encargando a uno de ellos tal incumbencia. LACRUz et al. (2009) p. 104. Manresa parece manifestarse en el mismo sentido al señalar que tales adjudicaciones se efectúan por conveniencia de todos los herederos. MANRESA y NAVARRO (1907), p. 777. En el sentido contrario Mingorance, quien sostiene que su finalidad principal es el pago de las deudas. MINGORANCE (2004), p. 116. Es probable que en la tradición que antecedió al Código Civil español el propósito haya sido proteger el interés de los acreedores, pero a partir del Código Civil español, parece ser que mediante estas adjudicaciones los herederos buscan protegerse de ser demandados por el total de las deudas hereditarias, conforme a la responsabilidad solidaria que les cabe a este respecto. Ello explica que esta institución exista y se aplique no obstante no ser obligatoria para los herederos.
}

27 GuZMán (1982), p. 414.

28 GUZMÁN (1982), pp. 416-418. 
Específicamente el artículo 1286 señala que "Sea que el testador haya encomendado o no a el albacea el pago de sus deudas, será éste obligado a exigir que en la partición de los bienes se señale un lote o hijuela suficiente para cubrir las deudas conocidas". Luego, el artículo 1287 agrega que "La omisión de las diligencias prevenidas en los dos artículos anteriores, hará responsable a el albacea de todo perjuicio que ella irrogue a los acreedores. Las mismas obligaciones y responsabilidad recaerán sobre los herederos presentes que tengan la libre administración de sus bienes, o sobre los respectivos tutores o curadores, y el marido de la mujer heredera, que no está separada de bienes". Finalmente, el artículo 1336 dispone que "El partidor, aun en el caso del artículo 1318, y aunque no sea requerido a ello por el albacea o los herederos, estará obligado a formar el lote e hijuela que se expresa en el artículo 1286, y la omisión de este deber le hará responsable de todo perjuicio respecto de los acreedores".

Para comprender de mejor forma esta obligación, en la presente sección se analiza (A) el objeto de la obligación de formar la hijuela pagadora de deudas, (B) la situación jurídica de los bienes que integran la hijuela pagadora de deudas, (C) la posibilidad de adjudicar la hijuela pagadora de deudas a uno o más herederos, (D) las obligaciones y responsabilidades de los sujetos pasivos de esta obligación y (E) los efectos de la hijuela pagadora de deudas en la regla, según la cual las deudas hereditarias se dividen entre los herederos a prorrata de sus cuotas.

\subsection{El objeto de la formación de la hijuela pagadora de deudas}

Formar la hijuela pagadora de deudas "consiste en separar de la masa de bienes una cantidad suficiente para satisfacer las deudas hereditarias de que se tiene noticias" 29 . La hijuela pagadora de deudas propiamente tal, se formará para cubrir aquellas deudas que no pudiesen ser satisfechas durante la partición. Como señala LIRA "el partidor procura cancelar todas las deudas durante el juicio particional y solo por excepción se puede hacer una provisión de fondos para deudas probables o discutidas ${ }^{\prime \prime 30}$. En efecto, cuando las deudas pueden ser pagadas, no se requiere de la formación de hijuela de deudas alguna.

Así, si bien las deudas se procurarán pagar antes de efectuar la partición, algunas deudas hereditarias pueden quedar pendientes de pago. Tal situación puede deberse a que determinadas deudas no sean todavía exigibles, se

29 Escobar (1955), p. 41. En el mismo sentido Somarriva (2002), p. 393. En Somarriva (2013), pp. 536537. Afirma que la formación de la hijuela pagadora de deudas consiste en indicar los bienes con los cuales se van a pagar las deudas hereditarias.

30 LiRa URQueta (1948), p. 129. 
encuentren sujetas a plazo, ser deudas litigiosas o incluso condicionales ${ }^{31}$. De esta forma, con el propósito de conservar bienes suficientes para pagar dichas deudas, se separan bienes de la herencia de la masa partible formándose una hijuela especial al efecto.

De este modo, la hijuela pagadora de deudas es una manera de hacer efectiva la norma del artículo 959 del Código Civil, en cuya virtud las deudas hereditarias, como bajas generales de la herencia, deben deducirse de la masa hereditaria antes de llevar a efecto las asignaciones establecidas por la ley o el testamento. Así, las deudas hereditarias deberán pagarse durante la partición, y cuando ello no sea posible, deberán entonces reservarse bienes para su pago por medio de la hijuela pagadora de deudas.

La hijuela pagadora de deudas solo se extiende a las deudas conocidas. Deudas conocidas son en primer lugar, aquellas deudas que los acreedores han puesto en conocimiento de los herederos y albacea, luego de la apertura de la sucesión de la cual han sido notificados por medio de los avisos exigidos por el artículo 1285 del Código Civil.

Sobre este respecto, debe tenerse en cuenta que la redacción original del artículo 1285 del Código Civil mencionaba expresamente que la noticia de la apertura de la sucesión tenía el propósito de avisar a los acreedores y demás interesados de la apertura de la sucesión ${ }^{32}$. Es por esta razón que según dispone el artículo 1287 del Código Civil, la omisión de estos avisos hace responsable a los herederos y albacea de los perjuicios que sufran los acreedores ${ }^{33}$.

En segundo lugar, son deudas conocidas aquellas deudas que aun cuando no sean manifestadas por los acreedores, son reconocidas expresamente por los herederos al momento de formar el inventario. De esta forma, si los herederos

31 Claro Solar (2013), pp. 130-131; Domínguez Benavente y Domínguez Águila (1990), p. 580.

32 La redacción original del artículo 1285 era la siguiente "Todo albacea será obligado a dar noticia de la apertura de la sucesión por avisos publicados en el periódico del departamento, si lo hubiere, o no habiéndolo, en carteles que se fijarán en tres de los parajes más públicos de la ciudad cabecera; i cuidará de que se cite a los acreedores por edictos que se publicarán de la misma manera". Bello (1881-1893), p. 329.

33 En el derecho Alemán, existe alguna semejanza. En efecto, según expone Binder, sea a petición del heredero, del administrador de la herencia o del ejecutor testamentario, el tribunal de la herencia debe decretar la publicación de la convocatoria de los acreedores para la presentación de sus créditos dentro de un determinado plazo. Transcurrido dicho plazo, se dicta una resolución de exclusión, que indica los créditos presentados dentro de plazo y excluye los restantes acreedores. Los créditos excluidos quedan pospuestos a los créditos reconocidos y además respecto de ellos, los herederos responden solo limitadamente, esto es hasta el valor de los bienes de la herencia. BINDER (1953), p. 220. En Chile, debiendo publicarse la apertura de la sucesión para dar aviso a los acreedores la herencia, los acreedores que no hacen presente sus créditos también quedan en una situación desmejorada, pues no podrán alegar después perjuicios derivaos de no haber sido considerados para la formación de la hijuela pagadora de deudas. 
reconocen en el inventario la existencia de determinadas deudas, deberán pagarlas antes de efectuar la partición, o en su defecto, considerarlas para la formación de la hijuela pagadora de deudas.

\subsection{Situación jurídica de los bienes que integran la hijuela pagadora de deudas.}

La situación jurídica de los bienes que integran la hijuela pagadora de deudas es singular. Parece tratarse de bienes que habiendo sido de propiedad del causante, han sido transmitidos a los herederos, pero que en todo caso deben destinarse al pago de las deudas hereditarias.

Sobre este asunto, debe considerarse en primer lugar que los bienes que integran la hijuela pagadora son de propiedad de los herederos. Dichos bienes formaban parte de la herencia que les fuera deferida al momento de la apertura de la sucesión, y por tanto pertenecen a los herederos. Ahora bien, al haberse separados de la masa partible, la partición no ha operado respecto de ellos. Por tanto, los herederos son comuneros de los bienes que integran la hijuela pagadora de deudas.

Estos bienes en común tienen una particularidad. Por constituir la hijuela pagadora de deudas, deben ser destinados por los herederos al pago de las deudas hereditarias, en términos tales que de no cumplir con dicha norma de conducta, responden de los perjuicios que se irroguen a los acreedores.

Como puede observarse, esta institución podría asemejarse a un patrimonio de afectación. En efecto, podría considerarse como una "agrupación de bienes y deudas apreciables en dinero, con valor pecuniario, en torno a fin común"34.

No obstante esta semejanza, creemos que la hijuela pagadora de deudas no alcanza a producir una separación de patrimonios propiamente tal, separando los bienes destinados al pago de las deudas hereditarias por una parte, y el resto del patrimonio de los herederos por otra.

Dicha interpretación no tiene sustento en el Código Civil y además privaría al beneficio de separación de gran parte de su utilidad. El Código Civil solo impone una norma de conducta consistente que dichos bienes sean destinados al pago de las deudas hereditarias, debiendo responder los herederos de los perjuicios ocasionados por una conducta contraria, sin que exista una separación propiamente tal entre un patrimonio y otro.

En consecuencia, el acreedor personal del heredero podría ejecutar su crédito en bienes de la hijuela pagadora de deudas. No habiendo separación de patrimonios, para dicho acreedor la hijuela pagadora de deudas se trata de una res inter alias, sin que le sean oponibles sus obligaciones. Sin embargo, ello no

34 Figueroa Yañez (2008), p. 39. 
obsta a que para el heredero exista la obligación de destinar dichos bienes al pago de las deudas hereditarias, debiendo por tanto procurar pagar la deuda con bienes propios, o bien sustituir el embargo, para así no responder de los perjuicios ocasionados a los acreedores hereditarios.

\subsection{Posibilidad de adjudicar la hijuela pagadora de deudas a uno o más herederos determinados}

Habiendo dicho lo anterior, cabe preguntarse si acaso la totalidad de los bienes que integran la hijuela pagadora de deudas puede o no ser adjudicada a uno o más herederos en particular. Esta pregunta se extiende tanto a la posibilidad de efectuar esta adjudicación en la misma partición de la herencia, como también en cualquier momento después en el que convengan los herederos.

Sobre este respecto, y según fue referido supra ${ }^{35}$, en la tradición jurídica española que antecedió nuestro Código Civil, los bienes destinados al pago de las deudas hereditarias se adjudicaban a uno de los herederos, quien se constituía en pagador de dichas deudas, debiendo rendir cuenta al resto de los herederos del cumplimiento de su encargo ${ }^{36}$. De este modo, en el derecho español antiguo, el contador partidor parece haber tenido la libertad de constituir a uno de los herederos pagador de las deudas, sin requerir del consenso de los herederos.

En el derecho sucesorio español actual, aun cuando no existe una obligación legal de formar un lote o hijuela de bienes para cubrir las deudas hereditarias, es común que en la partición se formen lotes de bienes destinados a pagar deudas, adjudicados a uno o más herederos ${ }^{37-38}$, ya sea para el pago de deudas o en pago de deudas. En la adjudicación para el pago de deudas, la doctrina española discute si el adjudicatario debe ser visto como un mero mandatario,

\footnotetext{
35 Ver sección 2.2, supra.

36 TAPIA (1837), pp. 84 y ss.

37 Mingorance (2004), pp. 113 y ss.

38 Para Lacruz esta organización del pago de las deudas hereditarias no está pensada en beneficio de los acreedores, sino para liberar de la preocupación de ese pago a la colectividad de los herederos, encargando a uno de ellos tal incumbencia. LACruz et al. (2009) p. 104. Manresa parece manifestarse en el mismo sentido al señalar que tales adjudicaciones se efectúan por conveniencia de todos los herederos. MANRESA y NAVARRo (1907), p. 777. En el sentido contrario Mingorance, quien sostiene que su finalidad principal es el pago de las deudas. MinGORANCE (2004), p. 116. Es probable que en la tradición que antecedió al Código Civil español el propósito haya sido proteger el interés de los acreedores, pero a partir del Código Civil español, parece ser que mediante estas adjudicaciones los herederos buscan protegerse de ser demandados por el total de las deudas hereditarias, conforme a la responsabilidad solidaria que les cabe a este respecto. Ello explica que esta institución exista y se aplique no obstante no ser obligatoria para los herederos.
} 
el cual no recibe los bienes para sí, siendo un mero intermediario, o si por el contrario se hace verdadero propietario de los bienes, existiendo un cierto traspaso patrimonial ${ }^{39}$. En las adjudicaciones en pago de deudas en cambio, los bienes se entregan al adjudicatario como contraprestación de la asunción de deudas asumidas por este. En este caso, el adjudicatario se vuelve verdadero deudor de las deudas, sufriendo las diferencias que podrían existir entre las deudas asumidas y los bienes adjudicados ${ }^{40}$.

Suele entenderse que la adjudicación para pago de deudas es una operación de partición, y como tal puede ser efectuada por el contador partidor sin requerir del concierto de los restantes herederos, mientras que la adjudicación en pago de deudas sería un acto que se escapa del ámbito de la indivisión hereditaria y por lo tanto no podría ser efectuada por el contador partidor ${ }^{41}$.

Así las cosas, sea bastando la voluntad del contador partidor, o bien requiriéndose del consenso de los comuneros, la adjudicación de bienes para el pago de deudas efectuada a uno o más herederos, es admisible y frecuente en el derecho civil español.

En Colombia por su parte, país que adoptó el Código de Bello, también se sigue una solución similar. Como hace notarValencia Zea, en la partición resulta usual que una vez señalados los bienes para atender al pago de las deudas, "el partidor adjudique los mencionados bienes a uno de los herederos o a un tercero, para que cancele dichos gastos y deudas ${ }^{\prime \prime 2}$. Precisa que tales adjudicaciones implican un previo acuerdo de los herederos, puesto que la adjudicación implica una tradición de la propiedad, sin privar en todo caso a los acreedores del derecho de perseguir a los herederos para el pago de sus deudas conforme la regla de la división de las deudas hereditarias ${ }^{43}$.

En Chile no conocemos autor ni jurisprudencia que se refiera expresamente sobre esta materia. Sin embargo, de acuerdo a los artículos 1340 y 1359 del Código Civil, cualquiera de los herederos puede asumir mayor cuota en las deudas hereditarias que la correspondiente a prorrata, bajo alguna condición que sea aceptada por los otros herederos. En otras palabras, se requiere del acuerdo de los herederos para efectuar adjudicaciones con el cargo de pagar las deudas hereditarias.

La posibilidad de adjudicar la totalidad de la hijuela pagadora de deudas a un heredero en particular, parece también estar reconocida en el artículo 1526

\footnotetext{
39 Para un resumen de las posiciones ver Mingorance (2004), pp. 116 y ss.

40 Mingorance (2004), p. 105.

41 EsPEjO (2013), pp. 197 y ss.

42 Valencia (1977), p. 431.

43 Valencia (1977), p. 432.
} 
$\mathrm{n}^{\circ} 4$ del Código Civil, el cual dispone que cuando por testamento, o por convención entre los herederos, o por la partición de la herencia, se ha impuesto a uno de los herederos la obligación de pagar el total de una deuda, el acreedor podrá dirigirse o contra este heredero por el total de la deuda, o contra cada uno de los herederos por la parte que le corresponda a prorrata.

De este modo, formada la hijuela pagadora de deudas, en la partición podría adjudicarse la hijuela pagadora de deudas a uno o más herederos en particular, mediando acuerdo de los interesados en la operación particional ${ }^{44}$.

Ahora bien, como precisan los artículos 1340 y 1358 del Código Civil, los acreedores siempre podrán elegir cobrar sus créditos conforme a estos arreglos, o bien conforme a las reglas generales, exigiéndole a cada heredero el pago de la parte de la deuda que le corresponda según su cuota en la herencia.

Lo anterior no debe hacernos olvidar que frente a los acreedores, la obligación de formar y destinar la hijuela pagadora de deudas al pago de las deudas hereditarias es siempre de todos los herederos, sin importar las adjudicaciones que pudiesen acordar los herederos. De esta forma, si como resultado de la adjudicación de la hijuela pagadora de deudas, las deudas hereditarias no fueren pagadas, destinándose los bienes de la hijuela a un fin diferente, los herederos que hayan concurrido al acuerdo de adjudicación, podrán resultar responsables frente a los acreedores hereditarios. Así, los herederos deben cuidar que una vez adjudicada la hijuela pagadora de deudas, dichos bienes sean efectivamente destinados al pago de las deudas hereditarias.

\subsection{Obligaciones y responsabilidad del partidor, albacea y herederos}

Conforme a los artículos 1286, 1287 y 1336 del Código Civil, el albacea, los herederos y el partidor deben intervenir en la formación de la hijuela pagadora de deudas. Sin embargo, las obligaciones de cada uno de ellos y por tanto su responsabilidad, no son las mismas. Mientras las obligaciones del albacea y partidor se agotan con la formación de la hijuela de deudas, la de los herederos se extiende hasta la consecución de la finalidad por la que la hijuela de bienes fue formada, esto es, el pago efectivo de las deudas hereditarias.

\footnotetext{
44 Sobre este asunto puede consultarse fallo Vial CON SANTA ANA y OtRo (1905), Corte Suprema, 29 de julio de 1905. En este interesante fallo, comentado por don Luis Claro Solar, se discute la naturaleza contractual de la partición, resolviendo la Corte que las adjudicaciones de bienes efectuadas en una partición no tienen naturaleza contractual. Sin pretender abordar aquí esta cuestión, resulta interesante notar que el asunto de suyo difícil, se vuelve aún más complejo cuando en una partición no solo se adjudican bienes en proporción a la cuota de cada heredero, sino que además, se pactan obligaciones de pago de determinadas deudas, como contraprestación a adjudicaciones de bienes adicionales a los que corresponderían por la sola cuota. Esta es precisamente la situación sobre la que trata el fallo a que hacemos referencia.
} 
La razón de esta diferencia, radica en que los herederos deben pagar las deudas hereditarias, y por tanto, una vez formada la hijuela pagadora de deudas, deben procurar que los bienes que la integran sean destinados efectivamente al pago de las deudas hereditarias conocidas.

En este sentido se ha manifestado la jurisprudencia colombiana, la cual ha entendido que el partidor no incurre en falta si no determina la persona a quien se le adjudica la hijuela pagadora, pues en tal caso "son los herederos quienes deben atender al pago de las deudas con los valores señalados en la hijuela"45. Asimismo, tampoco se considera objetable al partidor el que el lote o hijuela de bienes resultare excesivo o insuficiente, salvo que su formación haya sido arbitraria. Esto es, "si manifiestamente los bienes indicados para la hijuela son insignificantes, la partición puede ser objetada, pues la ley dice en forma expresa que la hijuela debe indicar bienes suficientes" ${ }^{\prime 4}$.

Según los artículos 1287 y 1336 del Código Civil, los herederos, el albacea y el partidor son responsables de los perjuicios que irrogue a los acreedores la omisión de la formación de la hijuela pagadora de deudas.

¿Cuáles son estos perjuicios y cuándo se originan? Estos perjuicios surgen de la necesidad de cobrar sus créditos por parcialidades a los distintos herederos, a prorrata de sus cuotas en la herencia, quedando expuestos de sufrir la insolvencia de alguno de los herederos ${ }^{47}$. De esta forma, los perjuicios parecen originarse cuando los acreedores no logran cobrar la totalidad de su crédito por la insolvencia de uno o más herederos.

Ahora bien, debe tenerse presente que la obligación de indemnizar estos perjuicios no altera la regla según la cual los obligados a pagar las deudas hereditarias son los herederos, y solo a prorrata de sus cuotas en la herencia. El albacea y el partidor no son responsables de pagar las deudas hereditarias. Lo que sucede en realidad, es que si los acreedores hereditarios sufren perjuicios derivados de la no formación de la hijuela de deudas, el albacea y el partidor tendrán la obligación de indemnizar dichos perjuicios.

Así fallaron antaño nuestros tribunales al rechazar una demanda interpuesta por un acreedor hereditario en contra de un juez partidor que no había formado la hijuela pagadora de deudas, estimando que no se había acreditado en autos, que el demandante hubiera sufrido perjuicios ni que hubiese primero exigido el pago a los herederos obligados de hacerlo ${ }^{48}$.

45 ValCenCia Zea (1977), p. 448.

46 Valcencia Zea (1977), p. 448.

47 Claro Solar (2013), pp. 131 y ss.

48 Corte de Apelaciones de Talca, 16 de mayo de 1900 . El considerando $2^{\circ}$ de la referida sentencia dispone que "la responsabilidad que el art. 1336 impone al partidor que omite la formación del lote o 
Existiendo más de un obligado a indemnizar los perjuicios ocasionados a los acreedores hereditarios por la falta de la hijuela pagadora de deudas, surge la necesidad de determinar si dicha responsabilidad es o no solidaria, de modo tal que pueda ser exigida íntegramente a cualquiera de los herederos, partidor y albacea al arbitrio de los acreedores afectados.

Sobre este punto, Gatti ${ }^{49}$ sostiene que entre los herederos y el albacea no puede existir solidaridad, pues la solidaridad no se presume, pero que en todo caso no se trata tampoco de una responsabilidad subsidiaria, pues se trata de unas mismas obligaciones para los herederos y el albacea; y ambos estarían en pie de igualdad.

Por nuestra parte, creemos que se trata de responsabilidad solidaria. Ello por dos razones: en primer lugar, suele entenderse que la responsabilidad de indemnizar perjuicios ocasionados por infracción de normas legales se rige por las reglas de la responsabilidad extracontractual ${ }^{50}$, y por tanto existiría solidaridad entre quienes participen de la infracción, en atención a lo dispuesto en el inciso primero del artículo 2317 del Código Civil. En segundo lugar, la omisión de la hijuela de deudas supone en alguna medida mala fe o culpa grave de los herederos en fraude de los acreedores hereditarios. En efecto, al tratarse de deudas conocidas, quienes heredan sin formar la hijuela de deudas, han decidido a sabiendas no destinar los bienes de la herencia al pago de las deudas hereditarias. El albacea y partidor por su parte, se hacen partícipes de este fraude al no exigir la formación de la hijuela pagadora de deudas, no obstante su posición de garantes. Así, y siguiendo lo dispuesto en el inciso segundo del artículo 2317 del Código Civil, existirá acción solidaria por los perjuicios ocasionados por ese fraude.

Por ello, si el partidor, albacea y herederos cometen la infracción de no formar la hijuela pagadora de deudas, cada uno de ellos será solidariamente responsable de todo perjuicio ocasionado a los acreedores hereditarios.

Distinta será la situación en que la infracción no sea cometida por todos, caso en el cual solo serán responsables quienes hayan cometido la falta. Esto podría ocurrir si el albacea solicita en el juicio particional que se forme la hijuela de deudas, pero su petición no es oída ni tenida en cuenta por el juez partidor ni por los herederos.

\footnotetext{
hijuela de deudas es sólo por los perjuicios que esta omisión causare a los acreedores, i no consta de autos que el demandante hubiera sufrido ninguna clase de perjuicios, ni aun que hubiera reclamado el pago de su asignación de los herederos obligados a hacerlo".

49 GatTI (1956), p. 240.

50 Aun cuando doctrina tradicional ha sostenido que en Chile las normas de responsabilidad contractual son el derecho común, la doctrina actual se inclina por la opinión contraria, y con ella reciente jurisprudencia. Así en CorRal (2013), pp. 35 ss.
} 


\subsection{La obligación de formar la hijuela pagadora de deudas y la regla según la cual la cuota del heredero insolvente no grava a los demás}

La comprensión de la obligación de formar la hijuela pagadora de deudas es esencial para entender cómo el derecho civil chileno resuelve la forma en que las deudas hereditarias deben ser pagadas y soportadas por cada uno de los herederos.

En efecto, si bien el artículo 1354 Código Civil establece que las deudas hereditarias se dividen entre los herederos a prorrata de sus cuotas, agregando el artículo 1355 que la cuota del heredero insolvente no grava a los demás, los efectos de esta regla son grandemente limitados por la hijuela pagadora de deudas.

La división de las deudas hereditarias entre los herederos a prorrata de sus cuotas en la herencia, según la regla nomina ipso iure divisa ${ }^{51}$ proviene de una tradición que se remonta a lo menos a la Ley de las XII Tablas. No obstante, la cuestión de la división de las deudas hereditarias ha sido desde antiguo objeto de grandes reparos, sosteniéndose que la división de las deudas hereditarias produce un perjuicio indebido en los acreedores hereditarios. Así por ejemplo, Pothier hace una defensa de esta norma, refutando las diferentes objeciones y críticas que se esgrimen contra ella, reconociendo en todo caso ciertas excepciones en su aplicación ${ }^{52}$. Por su parte, García Goyena hace duras críticas a la misma ${ }^{53}$.

Dichas críticas han llevado a que en ciertas legislaciones comparadas, se haya optado por una norma diversa, según la cual los acreedores pueden exigir a cualquiera de los herederos el total de la deuda hereditaria, sin importar su cuota en la herencia. Tal es el caso de los derechos de España ${ }^{54}$, y en cierta medida, Alemania ${ }^{55}$.

Pues bien, en el Código Civil existe una situación particular, en donde la hijuela pagadora de deudas busca dar solución a los problemas que ocasiona la división de las deudas hereditarias. En particular, limita la aplicación de la regla, según la cual la cuota del heredero insolvente no grava a los demás.

En efecto, tanto en la redacción las diferentes versiones del artículo 1355 del Código Civil -artículo que consagra la regla según la cual la cuota del heredero insolvente no grava a los demás-, como en las notas de Bello a dicha norma, se observa que se buscó la forma de que esta norma no desmejorase de forma injusta la posición de los acreedores hereditarios.

\footnotetext{
51 GuZMán (2013), p. 611.

52 Pothier (1961), p. 187.

53 García Goyena (1852), pp. 280-281.

54 LACRUz et al. (2009), pp. 102 y ss.

55 Binder (1953), pp. 246 y ss.
} 
Así, en el artículo 11 del título VI del Proyecto de $1841^{56}$, Bello consignó una nota la cual decía que esta disposición no podía perjudicar a los acreedores hereditarios cuando el pago de las deudas hereditarias se efectuara antes de la partición que es el orden regular, sino solo cuando después de la partición sobreviniese una deuda de que antes no se tuvo conocimiento ${ }^{57}$. En el texto del Proyecto de 1846 dicha nota fue incorporada al articulado, al establecerse que la porción de una deuda hereditaria cuyo pago se reclama después de la partición, y que no fuere completamente satisfecha por insolvencia de alguno de los herederos, no grava a los coherederos ni a los legatarios ${ }^{58}$.

Pues bien, en el Proyecto Inédito este precepto adquirió su redacción definitiva, en la que junto con ser más simple, incorpora la frase final "excepto en los casos del artículo 1287 inciso segundo"59. Dicha excepción consigna la responsabilidad que tienen los herederos que han omitido la obligación de formar la hijuela pagadora de deudas, consistente en el deber de indemnizar todo perjuicio a los acreedores.

Este cambio se efectuó conjuntamente con la incorporación de la hijuela pagadora de deudas, la cual solo aparece en el Proyecto Inédito, sin que tenga antecedentes en los proyectos anteriores.

De este modo, habiéndose establecido la obligación de formar la hijuela pagadora de deudas, el legislador limitó la aplicación de la regla según la cual la cuota del heredero insolvente no grava a los demás. En particular, los efectos nocivos de la división de las deudas en los acreedores hereditarios, se verifican en plenitud en solo una de las tres situaciones posibles. Así:

a) Si una determinada deuda es considerada en la formación de la hijuela pagadora de deudas, el acreedor podrá cobrar su crédito con dichos bienes, sin que en principio sufra perjuicio.

\footnotetext{
56 El texto completo del artículo 11 del título VI del Proyecto de 1841 es el siguiente: "Las porciones de una deuda hereditaria que no hubieren sido satisfechas por insolvencia de algunos de los herederos, no gravarán a los coherederos solventes, ni a los legatarios. La misma regla se extenderá a las cargas testamentarias, respecto de los asignatarios gravados". Bello (1881-1893), p. 53.

57 La nota completa es la siguiente: "Esta disposición no puede perjudicar a los acreedores cuando el pago de las deudas hereditarias se efectúa antes de la partición de los bienes, que es el orden regular. Sólo puede, pues, perjudiciales cuando sobreviene después de la partición una deuda de que antes no se tuvo conocimiento. En este caso, como los créditos i deudas se han dividido ipso jure entre los herederos, cada uno de éstos es sólo responsable a prorrata de su porción hereditaria". Bello (18811893), p. 53.

58 El texto del inciso $1^{\circ}$ del artículo 323 del Proyecto de 1846 es el siguiente: "La porción de una deuda hereditaria cuyo pago se reclama después de partidos i distribuidos los bienes, i que no fuere completamente satisfecha por insolvencia de alguno de los herederos, no gravará a los coherederos ni a los legatarios". Bello (1881-1893), p. 395.

59 Bello (1881-1893), p. 346.
} 
b) Si los herederos no consideran una determinada deuda hereditaria en la formación de la hijuela pagadora de deudas, estando en conocimiento de su existencia, deben responder frente al acreedor hereditario de los perjuicios derivados de la omisión de esta diligencia, sin que se aplique la regla según la cual la insolvencia de uno de los herederos no grava a los demás.

c) Si los herederos no están en conocimiento de la existencia una determinada deuda al momento de llevar a efecto la partición, y por lo tanto con justa causa no la consideran en la formación de la hijuela de deudas, no serán responsables de los perjuicios que puedan sufrir los acreedores respectivos. En otras palabras, la cuota del heredero insolvente no gravará al resto.

Así las cosas, los efectos adversos de la división de las deudas hereditarias se verifican en plenitud solo para el caso de deudas que no hayan estado en conocimiento de los herederos al momento de llevar a efecto la partición, y por lo tanto haya habido justa causa para no considerarlas en la formación de la hijuela de deudas.

Esto es concordante con lo que han sostenidos ciertos autores nacionales, quienes han afirmado que la formación de la hijuela pagadora de deudas protege a los acreedores hereditarios de los perjuicios que ocasiona la división de las deudas. Así por ejemplo, Claro Solar indica que el perjuicio que conlleva la división de las deudas hereditarias "se evita si antes de distribuir la herencia del deudor entre sus herederos se rebajan las deudas del caudal hereditario, pagando las deudas vencidas y formando un lote o hijuela para el pago de las otras $^{\prime \prime 60}$. Por su parte, Elorriaga sostiene que la hijuela pagadora de deudas es un medio para evitar o morigerar las consecuencias nocivas que produce la división de las deudas hereditarias, estimando que es una "buena garantía para los acreedores en lo que hace al pago de sus acreencias" ${ }^{\prime \prime 1}$.

\section{La hijuela pagadora de deudas y otras instituciones afines}

Llegados a este punto, conviene distinguir la hijuela pagadora de deudas de ciertas instituciones afines con las cuales presenta algunas semejanzas. Con tal propósito, a continuación nos referimos brevemente al beneficio de inventario y al beneficio de separación ${ }^{62}$.

60 Claro Solar (2013), p. 132.

61 Elorriaga (2015), p. 671.

62 Las referencias que se hacen en este trabajo al beneficio de inventario y al beneficio de separación tienen el solo propósito de distinguirlos de la hijuela pagadora de deudas. De esta forma, no pretendemos realizar estudio alguno sobre sus propiedades y efectos, ni tampoco sobre las cuestiones oscuras que se suscitan a su respecto. Para tales materias pueden consultarse Claro Solar (2013), pp. 69-129;301363; Domínguez Benavente y Domínguez Águila (1990), pp. 36-64. 


\subsection{El beneficio de inventario y la hijuela pagadora de deudas}

El art. 1247 del Código Civil señala que el beneficio de inventario consiste en no hacer, a los herederos que aceptan, responsables de las obligaciones hereditarias y testamentarias, sino hasta la concurrencia del valor total de los bienes que han heredado. En otras palabras, en virtud del beneficio de inventario, el heredero no responde por las deudas hereditarias y cargas testamentarias de manera ilimitada, sino solo hasta la concurrencia del valor de los bienes que ha heredado ${ }^{63}$.

Entre nosotros se ha discutido si el beneficio de inventario produce separación de patrimonios, esto es, si tras este beneficio los acreedores hereditarios pueden perseguir sus créditos en todos los bienes del heredero, o si por el contrario solo pueden hacerlo en los bienes que ha recibido del causante. En general ha primado la posición que niega la separación de patrimonios, permitiéndole a los acreedores hereditarios perseguir sus créditos en todos los bienes del heredero beneficiario, hayan o no formado parte de la sucesión ${ }^{64}$.

Dicho lo anterior, cabe preguntarse qué relación existe entre este beneficio del heredero y la hijuela pagadora de deudas. En realidad, aun cuando ambas instituciones dicen relación con el pago de las deudas hereditarias, ellas se distinguen claramente entre sí. El beneficio de inventario protege el interés del heredero, permitiéndole limitar su responsabilidad al valor de los bienes heredados. La hijuela pagadora de deudas en cambio, mira el interés de los acreedores hereditarios, en cuanto que impone sobre el heredero la obligación de destinar los bienes hereditarios al pago de las deudas hereditarias so pena de responder de los perjuicios ocasionados a los acreedores.

De esta forma, nada obsta a que un mismo heredero acepte con beneficio de inventario y deba formar una hijuela pagadora de deudas. Ello sucederá cada vez que existan herederos beneficiarios y que al momento de llevar a efecto la partición, hayan quedado deudas hereditarias pendientes de pago. En tal caso, la responsabilidad de los herederos beneficiarios se limitará al valor de los bienes de la herencia, pero deberán en todo caso formar una hijuela de bienes para solventar las deudas pendientes de pago.

\subsection{El beneficio de separación y la hijuela pagadora de deudas}

La relación y distinción de la hijuela pagadora de deudas con el beneficio de separación presenta mayor interés, pues ambas instituciones existen en

63 Elorriaga (2015), pp. 639 y ss.

64 Ver Claro Solar (2013), p. 102; Domínguez Benavente y Domínguez Águila (1990), p. 41. En contra de esta opinión Barros Errázuriz (1921), p. 639; Meza Barros (2000), pp. 323-325. 
beneficio de los acreedores hereditarios y ambas procuran también que los bienes hereditarios se destinen de manera preferente al pago de sus créditos. Con todo, y según pasamos a explicar, son instituciones que se distinguen entre sí.

El beneficio de separación puede entenderse como aquel beneficio de los acreedores hereditarios y testamentarios para exigir que los bienes dejados por el difunto no se confundan con los del heredero, a fin de pagarse de sus créditos con dichos bienes con preferencia a los acreedores propios del heredero ${ }^{65}$.

El principal efecto del beneficio de separación, es que en su virtud los acreedores hereditarios gozan, frente a los acreedores personales del heredero, de una preferencia para pagarse con los bienes de la herencia. Como contrapartida de lo anterior, y según se desprende del art. 1383 del Código Civil, los acreedores personales del heredero gozan a su vez de una preferencia para pagarse con los bienes del heredero. Luego de satisfechos los acreedores separatistas el excedente de los bienes del difunto sirve de prenda general a los acreedores del heredero. Del mismo modo, el excedente de los bienes del heredero sirve de prenda general a los acreedores separatistas.

Este beneficio se ejerce y existe con respecto a los acreedores personales del heredero ${ }^{66}$. En efecto, la preferencia de la que gozan los acreedores separatistas se hace valer contra ellos, pues son quienes sufrirán sus efectos. El heredero en cambio, no se ve afectado con el beneficio de separación; como señalaba don Luis Claro Solar, esta institución es extraña al heredero, sin que establezca obstáculo alguno a su derecho de administrar los bienes de la sucesión como sucesor del de cuyus ni de disponer de los mismos según mejor estime ${ }^{67}$.

La única afectación de su facultad de disponer viene dada por el art. 1384 del Código Civil, que indica que los acreedores separatistas pueden impugnar todos los actos de enajenación de bienes efectuados por el heredero en los seis meses siguientes a la apertura de la sucesión, en la medida que estas enajenaciones no hayan tenido por objeto el pago de créditos hereditarios o testamentarios ${ }^{68}$.

Los efectos de la hijuela pagadora de deudas son diferentes. Esta institución no genera una preferencia para el pago de los acreedores hereditarios que pueda hacerse valer contra los acreedores personales del heredero. En realidad, la hijuela de deudas solo vincula al heredero con los acreedores del causante, imponiéndole al primero la obligación de desinar ciertos bienes de la herencia al pago de las deudas hereditarias. Así, en la relación jurídica que da lugar la hijuela pagadora de deudas, solo son partes el heredero y los acreedores

65 Claro Solar (2013), p. 302; Elorriaga (2015), p. 731.

Claro Solar (2013), pp. 361-362. 
hereditarios (además del partidor y el albacea si lo hubieren); los acreedores personales del heredero en cambio son terceros ajenos.

Por ello, la hijuela pagadora de deudas no impide al acreedor personal del heredero ejecutar su crédito en bienes de la hijuela pagadora de deudas. No habiendo separación de patrimonios, ni existiendo preferencia alguna que pueda ejercerse en su contra, la hijuela pagadora de deudas es una res inter alias, sin que le sean oponibles las obligaciones que ella genera. El efecto que sí produce la hijuela pagadora de deudas, es que afecta las facultades de administrar y disponer de los bienes hereditarios que tiene el heredero, en el sentido de imponerle el deber de destinar los bienes de la hijuela al pago de las deudas hereditarias, en términos tales que de no hacerlo, responderá de los perjuicios que dicho omisión irrogue a los acreedores hereditarios.

De esta forma, si bien ambas instituciones protegen el interés de los acreedores hereditarios, lo hacen en ámbitos diversos y complementarios. El beneficio de separación protege el interés del acreedor hereditario en lo que respecta a las arremetidas que puedan realizar los acreedores personales del heredero. La hijuela pagadora de deudas en cambio, protege el interés del acreedor hereditario en lo que respecta a la conducta y proceder del heredero.

\section{Participación de los acreedores hereditarios en la formación de la hijuela pagadora de deudas}

Habiéndonos referido al objeto y función de la hijuela pagadora de deudas, resta analizar la participación que cabe a los acreedores hereditarios en su formación. Buscamos responder si acaso los acreedores hereditarios pueden pedir judicialmente que se forme la hijuela pagadora de deudas, separándose bienes suficientes para tal efecto.

Sobre este respecto, tanto la ley como la antigua jurisprudencia reconocen el derecho de los acreedores hereditarios de solicitar en el juicio particional la formación de la hijuela pagadora de deudas.

\subsection{Fuentes normativas y jurisprudenciales del derecho de los acreedores hereditarios de exigir la formación de la hijuela pagadora de deudas}

El artículo 1285 del Código Civil exige dar noticia de la apertura de la sucesión a los acreedores y demás interesados. Dichos avisos tienen por objeto que los acreedores hereditarios puedan hacer valer sus derechos en la sucesión, incluyendo las acreencias que tuvieren en contra del haber hereditario ${ }^{69}$. De esta

69 Bello (1881-1893), p. 329. 
forma, el albacea y los herederos, conociendo los créditos de los acreedores, se encontrarán en condiciones de señalar los bienes con los cuales formar la hijuela pagadora de deudas. Esta relación se desprende del sentido mismo de la norma, de su ubicación, y de la sanción establecida en el artículo 1287, esto es, la indemnización de perjuicios.

De esta forma, conforme al Código Civil, los acreedores hereditarios tienen el derecho de hacer presente sus derechos en la sucesión, con el objeto de que sus acreencias sean consideradas para la formación de la hijuela pagadora de deudas.

Esta facultad se encontraría además reconocida en el Código de Procedimiento Civil. En efecto, el artículo 23 del Código de Procedimiento Civil permite a los terceros que tengan interés actual en los resultados del juicio, intervenir en él, aun cuando su interés sea independiente del de las partes principales del juicio.

Pero todavía más, el artículo 656 del Código de Procedimiento Civil, otorga una acción precisa para hacer valer este derecho en el juicio particional. Así, el Código de Procedimiento Civil prescribe que los acreedores que tengan derechos que hacer valer en los bienes comprendidos en la partición, podrán ocurrir ante el partidor o ante la justicia ordinaria a su elección. Dicho de otro modo, los acreedores hereditarios tienen el derecho alternativo de acudir ante el partidor o ante la justicia ordinaria para requerir la formación de la hijuela pagadora de deudas.

En los antecedentes históricos del artículo 656 del Código de Procedimiento Civil, encontramos una referencia expresa a la posibilidad de accionar que tiene los acreedores hereditarios para exigir la formación de la hijuela pagadora de deudas. Así, don José Bernardo Lira señalaba en su Prontuario de los Juicios lo siguiente: "Si los herederos comenzaren la partición antes de cubrir todas las deudas hereditarias i testamentarias, pueden los acreedores o demandarlos ante la justicia ordinaria, siendo exigibles sus créditos, u ocurrir al partidor para que tenga presente sus derechos i los considere en la liquidación de la herencia, sin que por esto se entienda que quedan ellos sometidos al compromiso. Es conveniente esta presentación porque la lei tiene ordenado que en todo caso $i$ aunque no sea requerido a ello el albacea o herederos, forme el partidor un lote o hijuela suficiente para cubrir las deudas conocidas" ${ }^{\prime 70}$.

Así, Lira faculta a los acreedores hereditarios para que ocurran al partidor con el objeto que tenga presente sus derechos y los considere en la liquidación de la herencia, señalando que esta presentación es conveniente, pues la ley

70 LIRA (1886), p. 360. 
requiere que el partidor forme una hijuela de bienes suficientes para cubrir las deudas conocidas.

La semejanza de este texto con el artículo 656 del Código de Procedimiento Civil, tanto en lenguaje como en contenido, parecen ser suficientes para concluir que el artículo 656 del Código de Procedimiento Civil se basó en este texto. Confirma esta tesis el que su autor fue uno de los redactores principales del Código de Procedimiento Civil, siendo su Prontuario de los Juicios una de las obras que ejerció mayor influencia ${ }^{71}$.

Los primeros comentaristas del Código de Procedimiento Civil confirman la referencia que existe entre el artículo 656 y la hijuela pagadora de deudas, en cuanto mencionan al artículo 1286 del Código Civil dentro de las concordancias del artículo 656 del Código de Procedimiento civil ${ }^{72}$.

Por su parte, la antigua jurisprudencia nacional también ha reconocido que los acreedores hereditarios pueden pedir en el juicio particional la formación de la hijuela pagadora de deudas.

Así, la Corte de Apelaciones de la Serena reconoció el derecho de los acreedores hereditarios de pedir al partidor que tenga presente sus acreencias al momento de formar la hijuela pagadora de deudas ${ }^{73}$. La misma Corte, en otro fallo estableció además que el partidor debe formar la hijuela pagadora de deudas, aun cuando se trate de una deuda discutida en juicio, pues basta que se reconozca la posibilidad de que se haga efectiva, para que el partidor esté en el deber de formar el lote o hijuela de deudas ${ }^{74}$.

Resulta interesante mencionar que la jurisprudencia ha precisado que la participación de los acreedores hereditarios en el compromiso solo se limita a la legitimidad para hacer valer sus derechos en los bienes de la herencia, y no a inmiscuirse en los actos de una partición como verdaderos comuneros, privándoles por tanto del derecho de solicitar facción de inventario solemne ${ }^{75}$.

\footnotetext{
71 LAZO (1918), p. 13.

72 Toro Melo y Echeverría I Reyes (1902), p. 647; Lazo (1918), p. 656.

73 Herederos de Miguel Conde i Antonia Perez (1883d los acreedores hereditarios pueden ocurrir ante el partidor para pedirle que tenga presente sus acreencias al formar la hijuela pagadora de deudas, pero sin que por eso deban queda sujetos al compromiso".

74 Corte de Apelaciones de La Serena, 16 de agosto de 1873. El considerando tercero expresa lo siguiente: "3० Que del espediente acompañado consta que hai un juicio pendiente sobre cobro de pesos contra la sucesión de don Justo Madina, cuyos bienes se tratan de partir, i aun cuando no esté declarada judicialmente la obligación de pagar esa deuda, basta que se reconozca la posibilidad de que se haga efectiva, para que el partidor esté en el deber, conforme a lo dispuesto en el art. 1336 del Código Civil de formar el lote o hijuela que se expresa en el art. 1286 del mismo Código".
}

75 Corte de Apelaciones de Talca, 10 de octubre de 1906. 


\subsection{Acreedores hereditarios que pueden exigir la formación de la hijuela pagadora de deudas}

Dicho lo anterior, cabe preguntarse si el derecho de exigir judicialmente la formación de la hijuela pagadora de deudas puede ser impetrado judicialmente por cualquier acreedor o si se requiere de algún título que dé cuenta de su crédito. Aun cuando el asunto no encuentra una solución inmediata en el texto de la ley, creemos que es necesario que el acreedor cuente con el título documental de su crédito.

Esta exigencia concuerda con lo prescrito en el artículo 1255 del Código Civil, el cual señala que tendrá derecho de asistir a la facción de inventario "todo acreedor hereditario que presente el título de su crédito". Si la ley limita el derecho de participar de la facción de inventario a los acreedores que presenten el título de su crédito, parece razonable una exigencia similar para poder solicitar que un crédito sea considerado en la formación de la hijuela pagadora de deudas.

A lo anterior, cabe agregar que el art. 1379 del Código Civil señala que para que pueda impetrarse el beneficio de separación no es necesario que lo que se deba sea inmediatamente exigible; basta que se deba a día cierto o bajo condición. Estimamos que este mismo criterio puede seguirse para la hijuela pagadora de deudas, y en mayor medida todavía atendiendo el carácter eminentemente cautelar o conservativo que tiene esta institución.

Ahora bien, creemos que basta que el título sea justificativo del crédito, sin que sea necesario que sea un título indubitable. Así, parece razonable aplicar un criterio no más exigente que el requerido en los concursos y quiebras para la verificación de créditos.

Debe tenerse en cuenta que la hijuela pagadora de deudas tiene un cierto carácter cautelar, en cuanto que reserva bienes para un pago futuro, sin que sus efectos sean demasiado gravosos para los herederos. Por ello, el derecho puede aceptar que la certidumbre del crédito no sea completa, bastando una presunción razonable. En el intertanto, los herederos deberán procurar que los bienes se reserven para el pago de las deudas hereditarias, sin que suponga un reconocimiento del crédito. Por esta misma razón, nada obsta que un determinado crédito sea considerado para la formación de la hijuela de deudas, y que al mismo tiempo continúe discutiéndose la existencia o cuantía del mismo en sede jurisdiccional. Así, falló antiguamente la Corte de la Serena en el fallo antes citado ${ }^{76}$.

Lo que hemos apuntado en los numerales anteriores creemos que ayuda a entender el verdadero sentido del artículo 656 del Código de Procedimiento

76 Corte de Apelaciones de La Serena, 16 de agosto de 1873. 
Civil. En la doctrina clásica existe controversia sobre si es necesario o no que los comuneros reconozcan la existencia de los créditos, para que el partidor sea competente para conocer de las reclamaciones que hagan los terceros acreedores.

Claro Solar ${ }^{77}$ y con él la jurisprudencia ${ }^{78}$, han entendido que el derecho que el artículo 656 del Código de Procedimiento Civil reconoce a los acreedores hereditarios, supone que los derechos de estos acreedores sean reconocidos por los comuneros, y solo se trata de hacerlos efectivos. No sería aplicable al caso de derechos reclamados por los supuestos acreedores y que negaran los herederos, siendo en tal caso necesario la resolución de la justicia ordinaria.

Contra ello, Somarriva sostiene que si fuese necesario que los herederos reconozcan la acreencia para que el acreedor pueda ocurrir ante el partidor, el artículo 656 del Código de Procedimiento Civil carecería por completo de objeto. El que un tribunal sea competente para conocer una determinada materia "lleva involucrado el derecho del juez para aceptar o negar la petición que se le formula; si el partidor solo pudiere aceptar la petición del acreedor cuando los comuneros están de acuerdo en ella, ya no actuaría como juez" ${ }^{\prime 79}$.

En nuestra opinión, la cuestión se resuelve entendiendo que la competencia dada al juez partidor sobre esta materia se limita a los derechos que los acreedores hereditarios pueden hacer valer sobre bienes comprendidos en la partición y no de conocer o resolver sobre la existencia o cuantía de sus créditos. La discusión sobre la existencia o no del crédito es ajena al compromiso mismo, siendo materia de competencia exclusiva de la justicia ordinaria. Así, es admisible que el acreedor discuta la existencia de su crédito en sede ordinaria pero al mismo tiempo reclame la formación de la hijuela pagadora de deudas ante el juez partidor.

En este sentido parece haberse manifestado un voto disidente de antigua jurisprudencia, al pronunciarse por declarar incompetente a un juez árbitro para conocer del cobro de una determinada acreencia por reclamar a una suma de dinero y no referirse a los bienes comprendidos en la partición ${ }^{80}$.

\footnotetext{
77 Claro Solar (2013), p. 151.

78 Corte de Apelaciones de Talca, 3 de noviembre de 1911.

79 Somarriva (2012), p. 350.

80 Corte de Apelaciones de Talca, 3 de noviembre de 1906. El voto disidente del señor Ministro Fidel Urrutia expresa lo siguiente "si es verdad que, según el art. 812 del citado Código, los terceros acreedores que tengan derechos que hacer valer sobre los bienes comprendidos en la partición, pueden ocurrir al partidor o a la justicia ordinaria, a su elección, en el caso contemplado, el derecho que ejercita don Carlos del Campo, es el pago de un crédito en la forma que él lo menciona i nó sobre bienes comprendidos en la partición".
} 


\section{Implicancia de la hijuela pagadora de deudas}

Comprendida de este modo, la obligación de formar la hijuela pagadora de deudas cumple una función sustancial en el sistema de responsabilidad por las deudas hereditarias. Tal como hemos visto, la hijuela pagadora de deudas consagra en el derecho civil chileno, la obligación de los herederos de destinar los bienes de la herencia primeramente al pago de las deudas hereditarias conocidas, otorgando una protección especial a los acreedores de la herencia.

De esta forma, la hijuela pagadora de deudas complementa el artículo 959 del Código Civil, el cual exige que las deudas hereditarias sean deducidas de la herencia antes de llevar a efecto las asignaciones legales y testamentarias. Cuando las deudas hereditarias no pudiesen pagarse durante la partición, deberán entonces reservarse bienes para su pago por medio de la hijuela pagadora de deudas.

En virtud de lo anterior, no nos parece del todo acertada la afirmación de algunos, según la cual en el derecho civil chileno no existiría obligación de liquidar la herencia antes de que los herederos se hagan de los bienes hereditarios. Quienes piensan de este modo, sostienen que esta concepción sería una consecuencia del principio de la continuación de la personalidad del difunto ${ }^{81}$. Otros, la entienden también como una consecuencia de la responsabilidad ultra vires del heredero ${ }^{82}$. Por último, algunos sostienen que ello se desprende del artículo 1374 del Código Civil ${ }^{83}$, el cual en vez de disponer una forma ordenada de liquidación y pago de las deudas hereditarias, establece que "se pagará a los acreedores hereditarios a medida que se presenten".

Esta postura parecería ser razonable, pues una liquidación previa del patrimonio hereditario es principio no sería admisible en un sistema de sucesión en la persona. Así lo entienden Planiol y Ripert, al sostener que es "esta una consecuencia natural del principio de la continuación, porque una liquidación autónoma y previa a la partición del patrimonio del de cuyus produciría una especie de sucesión en el activo neto que solamente se explicaría en un régimen de sucesión de bienes" ${ }^{\prime \prime 4}$.

Sin embargo, en el derecho civil chileno, y según hemos expuesto en este trabajo, los bienes de la herencia deben destinarse primero al pago de las deudas hereditarias y en tal sentido existe una cierta obligación de liquidar la herencia. Ahora bien, lo que sucede es que ello no significa que la herencia sea

\footnotetext{
Escobar Riffo (1955), pp. 124-125.

Domínguez Benavente - Domínguez Águila (1990), p. 339.

Elorriaga (2015), p. 685; y Escobar (1955), pp. 124-125.

4 Planiol M. y Ripert J. (1933), p. 408.
} 
un patrimonio completamente autónomo e independiente del patrimonio de los herederos. Solo existe una obligación personal de los herederos, de destinar los bienes de la herencia preferentemente al pago de las deudas conocidas, debiendo responder de los perjuicios ocasionados a los acreedores hereditarios en caso de proceder de un modo diferente.

Por lo mismo, los herederos siempre podrán optar por dar a los bienes de la herencia un destino diferente, con la salvedad de tener que responder de los perjuicios que dicha decisión pudiera ocasionar a los acreedores hereditarios. Asimismo, los herederos siempre podrán salvarse de esta situación pagando las deudas hereditarias, sea con los bienes de la herencia o con unos distintos, pues los acreedores hereditarios serán satisfechos, y por tanto no habrán sufrido perjuicio.

De esta forma, lo que aquí se sostiene no se aparta completamente de la idea de sucesión en la persona y al principio de continuación de la persona del causante, pero sí modifica la forma de entender el fenómeno sucesorio. Según se ha explicado, la obligación de formar la hijuela pagadora de deudas, exige una cierta liquidación de la herencia ajena al modo tradicional de entender los sistemas de sucesión en la persona, denotando una cierta pervivencia del patrimonio del causante ${ }^{85}$.

\section{Conclusiones}

1. Según se desprende de las fuentes históricas del Código Civil, y en particular del derecho hispano antiguo, la hijuela pagadora de deudas es una institución que responde al principio, según el cual antes es pagar que heredar y a una noción residual de herencia.

2. La hijuela pagadora de deudas propiamente tal se forma solo para cubrir aquellas deudas que no fuesen pagadas durante la partición. Ello ocurrirá, por ejemplo, cuando existan deudas que no sean todavía exigibles, se encuentren

\footnotetext{
85 Ciertamente esta solución se aparta en alguna medida del prototipo de sucesión en la persona, tomando algunos elementos de la sucesión de bienes. Así, por ejemplo, en el derecho alemán, comúnmente considerado un sistema de sucesión de bienes, existe la obligación de reservar fondos para el pago de deudas que no pudiesen pagarse antes de efectuar la partición. Así, las deudas hereditarias deben ser pagadas antes de repartir los bienes a los herederos, siendo necesario convertir el caudal relicto en metálico en la medida que sea necesario para pagar dichas obligaciones. Ahora bien, si todavía no hubiesen vencido ciertas obligaciones, o si se tratase de deudas litigiosas, es necesario retener bienes o metálico para su pago posterior. KIPP, Theoddor (1951), p. 26. Tomar algunos elementos de la sucesión de bienes no significa apartarse totalmente del sistema de sucesión en la persona. En el antiguo Código Civil argentino existía una solución en cierto sentido semejante a la de Chile. Como explica Fornieles, los acreedores hereditarios pueden oponerse a la partición cuando no se han separado bienes suficientes para el pago de las deudas y cargas. Es obligación del partidor separar bienes suficientes para el pago de las deudas y cargas. Fornieles (1950), pp. 408-413.
} 
sujetas a plazo, sean deudas litigiosas o incluso condicionales. Una vez formada la hijuela pagadora de deudas, los herederos tienen la obligación de destinar dichos bienes al pago de las deudas hereditarias y no a otros fines, respondiendo solidariamente de los perjuicios que provengan de una conducta distinta. La hijuela de deudas se mantiene en comunidad salvo acuerdo distinto de los herederos.

3. En los distintos proyectos que antecedieron al Código Civil, consta que existió una especial preocupación por encontrar una solución adecuada al pago de las deudas hereditarias y en particular a la regla de la división de las deudas hereditarias entre los herederos a prorrata de sus cuotas en la herencia. Dicha cuestión parece haberse resuelto con la hijuela pagadora de deudas, asegurándole a los acreedores hereditarios que los bienes de la herencia se destinarían primeramente al pago de sus créditos y limitando los efectos de la regla según la cual la cuota del heredero insolvente no grava a los demás.

4. Los acreedores hereditarios que presenten el título en el que conste su crédito pueden solicitar judicialmente, tanto ante el juez partidor como ante la justicia ordinaria, que se forme la hijuela de deudas. No es necesario que el título sea indubitado, bastando que sea justificativo de su crédito, pudiendo incluso tratarse de un crédito discutido en juicio.

5. La implicancia de la hijuela pagadora de deudas radica en que consagra el principio en virtud del cual las deudas hereditarias deben pagarse en primer término con los bienes de la herencia, haciendo responsables a los herederos de los perjuicios que provengan de un proceder o actuar diferente. Dicha obligación afecta la manera general de entender el derecho sucesorio chileno, pues exige una cierta liquidación de la herencia, ajena al modo tradicional de entender los sistemas de sucesión en la persona denotando una cierta pervivencia del patrimonio del causante.

\section{BiBLIOGRAFÍA CITADA}

Barros Errázuriz, Alfredo (1921): Curso de Derecho Civil (Santiago de Chile, Imprenta Cervantes).

Bello, Andrés (188-1893): Obras Completas de don Andrés Bello (Santiago de Chile, Impreso por Pedro G. Ramírez).

Binder, Julius (1953): Derecho de Sucesiones (Traducc. José Luis Lacruz Berdejo, Barcelona, Editorial Labor S.A.).

Claro Solar, Luis (2013): Explicaciones de Derecho Civil Chileno y Comparado (Santiago de Chile, Editorial Jurídica de Chile), Tomo XVII.

Corral Talcianı, Hernán (2013): Lecciones de Responsabilidad Civil Extracontractual, Segunda edición (Santiago de Chile, Editorial Legal Publishing Chile). 
Domínguez Benavente, Ramón y Domínguez Águila, Ramón (1990): Derecho Sucesorio (Santiago de Chile, Editorial Jurídica de Chile).

ElorRIAGA De Bonis, Fabian (2015): Derecho Sucesorio, Tercera edición (Santiago de Chile, Editorial Thomson Reuters).

Escobar Riffo, Francisco (1955): Del pago de las deudas hereditarias y testamentarias (Santiago de Chile, Editorial Jurídica de Chile).

EsCRICHE, Joaquín (1842): Diccionario Razonado de Legislación Civil, Penal, Comercial y Forense (Madrid, Librería de Calleja e Hijos).

Espejo RuIz, Manuel (2013): La partición realizada por contador partidor testamentario (Madrid, Editorial Dykinson).

Figueroa YáÑez, Gonzalo (2008): El Patrimonio, Tercera edición (Santiago de Chile, Editorial Jurídica de Chile).

Fornieles, Salvador (1950): Tratado de Sucesiones (Buenos Aires, Editorial Soc. Anón. Editores).

García Goyena, Florencio (1852): Concordancias, motivos y comentarios del Código Civil español (Madrid, Imprenta de la Sociedad Tipográfico-Editorial).

Gatti, Hugo (1956): Albaceas (Montevideo, Biblioteca de Publicaciones Oficiales de la Facultad de Derecho y Ciencias Sociales de la Universidad de Montevideo).

Gonzales Palomino, José (1945): La adjudicación para pago de deudas (Alcalá de Henares, Imprenta Talleres Penitenciarios,).

Guzmán Brito, Alejandro (2013): Derecho Privado Romano, Segunda edición (Santiago de Chile, Editorial Legal Publishing Chile).

Guzmán Brito, Alejandro (1982): Andrés Bello Codificador (Santiago de Chile, Ediciones de la Universidad de Chile).

GuzMán Brito, Alejandro (1979): "Para la Historia de la fijación del Derecho Civil en Chile durante la República", en: Revista Historia (No 14), pp. 315-328.

KASER, Max (1968): Derecho Romano Privado (Traducc. José Santa Cruz Teijeiro, Madrid, Instituto Editorial Reus S.A.).

KIPP, Theoddor (1951): Derecho de Sucesiones, Tratado de Derecho Civil (Traducc. Ramón Ma Roca Sastre, Barcelona, Editorial Boch), Tomo V, Vol. 2.

Lacruz Berdejo, José Luis, Sancho Rebullida, Francisco de Asís, y otros (2009): Elementos de Derecho Civil, Sucesiones, Cuarta edición (Madrid, Editorial Dykinson), Tomo V.

Lazo, Santiago (1918): Código de Procedimiento Civil, Orígenes, Concordancias, Jurisprudencia (Santiago de Chile, Poblete Cruzar Hnos. Editores).

LIRA, José Bernardo (1886): Prontuario de los Juicios o Tratado de procedimientos judiciales i administrativos con arreglo a la legislación chilena, Cuarta edición (Santiago, Imprenta de El Correo), Tomo I. 
LiRa Urqueta, Pedro (1948): La Partición de Bienes (Santiago, Editorial Jurídica de Chile).

Llamas y Molina, Sancho (1852): Comentario crítico-jurídico-literal a las ochenta y tres Leyes de Toro (Madrid, Imprenta de la Compañía de Impresores y Librores del Reino).

Manresa y Navarro, José María (1907): Comentarios al Código Civil Español (Madrid, Imprenta de la Revista de Legislación).

Meza Barros, Ramón (2000): Manual de la sucesión por causa de muerte y donaciones entre vivos (Santiago de Chile, Editorial Jurídica de Chile).

Mingorance Gonzálves, Carmen (2004): El pago de las deudas hereditarias (Madrid, Editorial Dykinson).

Peña Bernaldo de Quiroz, Manuel (2009): La herencia y las deudas del causante, Tercera edición (Granada, Editorial Comares).

Planiol, Marcel y Ripert, Georges: Tratado Práctico de Derecho Civil Francés; Las Sucesiones (Traducc. Mario Díaz Cruz, La Habana, Editorial Cultural S.A. 1933), Tomo IV.

PothieR, Robert Joseph (1961): Tratado de las obligaciones (Traducc. No Indica. Buenos Aires, Editorial Bibliográfica Argentina).

Rodríguez Grez, Pablo (2002): Instituciones de Derecho Sucesorio (Santiago de Chile, Editorial Jurídica de Chile).

SOMARRIVA UndurRaga, Manuel (2002): Indivisión y Partición, Quinta edición (Santiago, Editorial Jurídica de Chile).

Somarriva Undurraga, Manuel, versión de Abeliuk, René (2013): Derecho Sucesorio, Octava edición (Santiago, Editorial Jurídica de Chile).

TAPIA, Eugenio (1837): Febrero Novísimo (Valencia, Imprenta de Ildefonso Mompie).

Toro Melo, David y Echeverría I Reyes, Aníbal (1902): Código de Procedimiento Civil Anotado (Santiago, Imprenta, Litografía i Encuadernación Barcelona).

Valcencia Zea, Arturo (1977): Derecho Civil, Sucesiones (Bogotá, Editorial Temis), Tomo VI.

\section{JURISPRUDENCIA CITADA}

Albornoz con Villalobos (1911): Corte de Apelaciones de Talca, 3 de noviembre de 1911, Gaceta de los Tribunales, Tomo II. No 1232, p. 833.

Beatriz Bustamante (1906): Corte de Apelaciones de Talca, 3 de noviembre de 1906, Gaceta de los Tribunales, (1906), Tomo I. № 179, p. 307.

González con Salazar (2012): Corte de Apelaciones de Chillán, 20 de julio de 2012, ID vLex: 395464138, fecha de consulta 7 de julio de 2014. 
Herederos de Miguel Conde i Antonia Perez (1883): Corte de Apelaciones de La Serena, 21 de noviembre de 1883, Gaceta de los Tribunales, (1883), No 3239, p. 1818.

Madina con Lorca (1873): Corte de Apelaciones de La Serena, 16 de agosto de 1873, Gaceta de los Tribunales, (1873), № 1742, p. 776.

Nolasco con Villalón (1906): Corte de Apelaciones de Talca, 10 de octubre de 1906, Gaceta de los Tribunales (1906), Tomo II. № 829, p. 252.

Ramírez con Morel (1900): Corte de Apelaciones de Talca, 16 de mayo de 1900. Gaceta de los Tribunales, (1900), Tomo I, pp. 746 y 805.

Vial con Santa Ana y Otro (1905): Corte Suprema, 29 de julio de 1905, Revista de Derecho y Jurisprudencia (1905-1906), Tomo III, Segunda Parte, Sección Primera, p. 66. 
